\title{
PHYTOCHEMICAL SCREENING FOR ANTIBACTERIAL COMPOUNDS OF SOME SEAWEED FROM COASTAL AREA OF ABU-QIR, ALEXANDRIA, EGYPT
}

\author{
Gehad M. T. Morsy*, Elsayed Kh. Bekhet**, Entesar A. Mohamed*, \\ Rawhya A. Salah EI Din* \\ *Botany and Microbiology Department, Faculty of Science, Al-Azhar University (Girls \\ Branch) \\ **Botany and Microbiology Department, Faculty of Science, Al-Azhar University (Assuit)
}

\begin{abstract}
:
In this study, antibacterial activities of four seaweeds (Pterocladia capillacea, Corallina mediterranea, Corallina officinalis, and Ulva lactuca) collected from Abu-Qir, Alexandria, Egypt during summer 2016. Their methanol/chloroform extracts were tested against four Gram-positive bacteria (Staphylococcus aureus, Staphylococcus epidermidis, Streptococcus sp. and Bacillus cereus, and two Gramnegative bacteria (Salmonella enterica, Proteus mirabilis). The results revealed that the number of algal extracts inhibited Bacillus cereus. On the other hand, no effect was shown on Proteus mirabilis. The n-Hexadecanoic acid was a fatty acid which recorded as active compound in Pterocladia capillacea extract was characterized by GC-MS analysis.
\end{abstract}

Key words: Antibacterial activity, GC-MS analysis, Methanol/Chloroform extract, Phytochemical Screening, Seaweeds.

\section{Introduction}

Marine algae were reported to produce a wide variety of bioactive secondary metabolites as antimicrobial, cytotoxic agents and the bioactive substances included alkaloids, polyketides, cyclic peptide, polysaccharide, phlorotannins, diterpenoids, sterols, quinones, lipids and glycerols (Cabrita $\boldsymbol{e t}$ al., 2010). Marine macro-algae are considered as the actual producers of some bioactive compounds with high activity (Shimizu, 1996). Seaweeds are potential source of bioactive compounds for the pharmaceutical industry in drug development.

Many of the seaweeds possess bioactive components which inhibit the growth of some of the Gram positive and Gram negative bacterial pathogens. (Govindasamy et al., 2012). In recent years research on the chemistry of seaweed has increased due to the need for compounds possessing bioactivities of possible pharmaceutical applications or other potential economic properties. Since marine 
organisms live in a significantly different environment from those of terrestrial organisms, it is reasonable to suppose that their secondary metabolites will differ considerably (Eahamban and Anatonisamy, 2012). It is now collectively acknowledged that the use of antimicrobials for both animals and humans can select for resistant bacteria populations. Emergence of antimicrobial resistance has become a serious worldwide problem. In fact, emerging antimicrobial resistance phenoltypes have been recognized among multiple zoonotic pathogens including Salmonella enterica serovar Typhimurium, Escherichia coli, Campylobacter jejuni (Taskin et al., 2007). The current study was performed to investigate the phytochemical constituents of four selected seaweeds to investigate their Methanol/Chloroform extracts as antibacterial activity and identified the bioactive compounds.

\section{Materials and Methods}

\section{Collection and identification of seaweeds:}

The studied algal species were collected during summer, 2016 from the coastal area of Abu-Qir, Alexandria, Mediterranean Sea, Egypt. Algal samples were cleaned from epiphytes, and necrotic parts were removed. Then, cleaned samples were rinsed with distilled water to remove any associated debris. The cleaned fresh materials were shade air-dried and ground into fine powder. The samples were identified as (Pterocladia capillacea (S.G.Gmelin) Bornet, Corallina mediterranea Areschoug, Corallina officinalis Linnaeus, and Ulva lactuca Linnaeus) as described by Fletcher (1987)

\section{Phytochemical screening}

Preliminary screenings of phytochemical constituents such as flavonoids was done according to (Feigl, 1966), volatile oil by (Bianco, 1990), alkaloids as described by (Shellard, 1957; Robinson, 1964), sterols and diterpenes (Fieser and Fieser, 1949, Schmidt, 1964, and Fransworth, 1966), protein, glycosides, saponins and carbohydrates (Tiwari et al., 2011), tannins and phenols by (Trease and Evans, 1989). 


\section{Preparation of seaweed extracts:}

Fifty grams powdered samples were extracted with methanol/chloroform (50:50, v/v) by maceration. Then the extracts were evaporated under reducing pressure to dryness at $45^{\circ} \mathrm{C}$ on a rotaevaporator (Bchi R114) and the residue was used for antibacterial assay by the well-diffusion method (Perez et al., 1990) and agar dilution method (Robert-Dernuet, 1995).

\section{Bacterial strains}

The test microorganisms used in this study included four Gram-positive (Staphylococcus aureus, Staphylococcus epidermidis, Bacillus cereus, Streptococcus sp.) and two Gram-negative (Salmonella enterica, Proteus mirabilis) were obtained from Faculty of Medicine, Assiut University, Egypt.

\section{Isolation and Identification of active compounds of the tested algae extracts}

The aliquots were directly injected into gas chromatography-mass spectrometry (GC-MS) for analysis. The method was based on Hashimoto et al . (2001), The identification of the antimicrobial compounds was based on comparison of retention times and computer matching of the mass spectra with those of the National Institute of Standards and Technology (NIST) library and by direct comparison with published data.

\section{Results and Discussion}

\section{Phytochemical screening of selected seaweeds}

The preliminary phytochemical analysis of the seaweed used in the present study has been studied and reported in Table (1), that showed the presence of alkaloids, carbohydrates, glycosides, saponins, phytosteroids, phenols, tannins, flavonoids, diterpens and proteins in the methanol/ chloroform extract of all selected seaweeds except phenols, tannins and flavonoids were absent in Corallina mediterranea, the similar results has been observed by Mohy El-Din and El-Ahwany (2016) for C. mediterranea and P. capillacea. 
Table (1): Phytochemical screening for (methanol-chloroform) extract of tested seaweeds.

\begin{tabular}{|c|c|c|c|c|}
\hline \multirow{2}{*}{ Phytochemical } & \multicolumn{4}{|c|}{ Algal Isolate } \\
\hline & P. capillacea & C. officinalis & C. mediterranea & U. lactuca \\
\hline Protein & + & + & + & + \\
\hline Phytosterols & + & + & + & + \\
\hline Glycosides & + & + & + & + \\
\hline Carbohydrate & + & + & + & + \\
\hline Diterpens & + & + & + & + \\
\hline Flavonoids & + & + & - & + \\
\hline Tannins & + & + & - & + \\
\hline Phenols & + & + & - & + \\
\hline Alkaloids & + & + & + & + \\
\hline Saponins & + & + & + & + \\
\hline
\end{tabular}

\section{Antibacterial activity of selected seaweeds:}

The antibacterial activities of the selected seaweeds in terms of the mean zone of inhibition diameters are shown in Table (2). The methanol/chloroform extracts of four seaweeds showed a variable inhibitory effect against bacteria, in which the following seaweed species (Pterocladia capillacea, Corallina officinalis and Corallina mediterranea) showed inhibitory effect against all tested bacterial strains except Proteus mirabilis, while Ulva lactuca showed inhibitory effect against Salmonella enterica $(8 \pm 1.5 \mathrm{~mm})$ and Bacillus cereus $(12.5 \pm$ $0.5 \mathrm{~mm}$ ). The highest zone of inhibition in the present study was recorded in the methanol/chloroform extract of red seaweed, Pterocladia capillacea with mean inhibition zone $(16.5 \pm 2 \mathrm{~mm})$ against Bacillus cereus with MIC value $0.25 \mathrm{mg} / \mathrm{ml}$. The ability of marine algae to produce secondary metabolites of potential interest has been documented by (Cabrita et al., 2010).

The results In Table (3) showed that Pterocladia capillacea had Minimum Inhibitory Concentration (MIC) at concentration $(0.25 \mathrm{mg} / \mathrm{ml})$ in the case of Bacillus cereus and Staphylococcus aureus with inhibition zone diameter (10.6 
$\mathrm{mm}$ and $10 \mathrm{~mm})$ respectively, and had MIC at concentration $(0.5 \mathrm{mg} / \mathrm{ml})$ in the case of Salmonella enterica with inhibition zone diameter $(7 \mathrm{~mm})$, while Corallina officinalis had MIC value $(0.5 \mathrm{mg} / \mathrm{ml})$ in the case of Staphylococcus aureus and Salmonella enterica with inhibition zone $(8 \mathrm{~mm}$ and $6 \mathrm{~mm})$ respectively, and had MIC value with Bacillus cereus at concentration (0.25 $\mathrm{mg} / \mathrm{ml}$ ) with inhibition zone diameter $(7 \mathrm{~mm})$.

According to earlier reports antibacterial activity depends on algal species, the efficiency of the extraction method (Radhika et al., 1997) and the resistance of the tested bacteria (Seenivasan et al., 2010). Rao and Parekh (1981); Padmakumar and Ayyakkannu (1997); Zeheng et al. (2001) reported that the species of Rhodophyta showed the highest antibacterial activity.

Table (2): The antibacterial activity of methanol/chloroform (50:50v/v) extract of selected seaweeds.

\begin{tabular}{|l|c|c|c|c|}
\hline \multirow{2}{*}{ Tested bacteria } & \multicolumn{4}{|c|}{ Mean Zone of inhibition (mm) } \\
\cline { 2 - 5 } & $P$. capillacea & C. officinalis & C. mediterranea & U. lactuca \\
\hline $\begin{array}{l}\text { Staphylococcus } \\
\text { aureus }\end{array}$ & $12 \pm 0.5$ & $11.5 \pm 1$ & $6.5 \pm 0.5$ & Nil \\
\hline $\begin{array}{l}\text { Staphylococcus } \\
\text { epidermidis }\end{array}$ & $8.5 \pm 0.5$ & $8.5 \pm 0.5$ & $9.5 \pm 0.5$ & Nil \\
\hline $\begin{array}{l}\text { Bacillus } \\
\text { cereus }\end{array}$ & $16.5 \pm 2$ & $14.5 \pm 1$ & $14 \pm 1.5$ & $12.5 \pm 0.5$ \\
\hline Streptococcus sp. & $13 \pm 0.5$ & $11.5 \pm 0.5$ & $8.5 \pm 0.5$ & Nil \\
\hline $\begin{array}{l}\text { Salmonella } \\
\text { enterica }\end{array}$ & $12 \pm 4$ & $13.5 \pm 1.5$ & $10.5 \pm 0.5$ & $8 \pm 1.5$ \\
\hline Proteus mirabilis & Nil & Nil & Nil & Nil \\
\hline
\end{tabular}

Where: Nil $=$ negative

Table (3): Inhibition zone diameter for MIC ( $\mathrm{mm})$ value of methanol/chloroform (50:50 v/v) of Pterocladia capillacea and Corallina officinalis.

\begin{tabular}{|c|l|c|c|c|c|}
\hline \multirow{2}{*}{ Bacteria species } & \multicolumn{4}{c|}{ Algal Species } \\
\cline { 2 - 6 } & Pterocladia capillacea & Corallina officinalis \\
\hline \multicolumn{2}{|c|}{ Concentration $(\mathrm{mg} / \mathrm{ml})$} & 0.25 & 0.5 & 0.25 & 0.5 \\
\hline \multirow{2}{*}{$\begin{array}{c}\text { Inhibition } \\
\text { zone }(\mathrm{mm})\end{array}$} & Bacillus cereus & 10.6 & 12.6 & 7 & 8.5 \\
\cline { 2 - 6 } & Staphylococcus aureus & 10 & 12.3 & - & 8 \\
\cline { 2 - 6 } & Salmonella enterica & - & 7 & - & 6 \\
\hline
\end{tabular}

Egyptian J. of Phycol. Vol. 19, 2018

$-51-$ 
The Data obtained from this study revealed that Rhodophyta had the highest antibacterial activity against the test bacteria, which was in agreement with the previous reports; the highest zone of inhibition in the present study was recorded in the methanol/chloroform extract of the red seaweed, Pterocladia capillacea. This result agree with the finding of Wefky and Ghobrial (2008) and Kolanjinathan et al. (2014) investigated some marine algae belonging to Phaeophyceae and Rhodophyceae, collected from different coastal areas of Alexandria for their antibacterial activity against fish pathogen, the results showed that the organic solvent extracts from several marine macro algae, including Pterocladia capillacea, had specific activity against the growth of pathogenic bacteria, also, the present study was in harmony with Mohy El-Din and ElAhwany (2016). They evaluated the antibacterial activity of Jania rubens, Corallina mediterranea and Pterocladia capillacea against human pathogenic bacteria, and they found that all extracts have antibacterial activity against the tested organisms and the highest zone of inhibition was recorded in the methanol extract of Pterocladia capillacea. In this study Bacillus cereus was found to be the most sensitive among the tested bacteria to all used algal extracts. Proteus mirabilis alone were resistant to all the seaweed extracts. It was reported that the Gram-positive bacterial strains were more susceptible to seaweeds extract than Gram-negative bacterial strains (Mhadhebi et al., 2012).

\section{Identification of phytochemical compounds.}

According to Gas chromatography-mass spectrometry analysis of the methanol/chloroform extract of Pterocladia capillacea, it is cleared that the active compound which responsible for the antibacterial activity was n-Hexadecanoic acid (51\%) (Figure 1). This result was agree with the previous reports (McGaw et al., 2002; Yff et al., 2002; Seidel and Taylor, 2004; Yin et al., 2011; Kalaivani et al., 2012) who assumed that palmitic acid (n-Hexadecanoic acid) has been responsible for the antibacterial activity. 


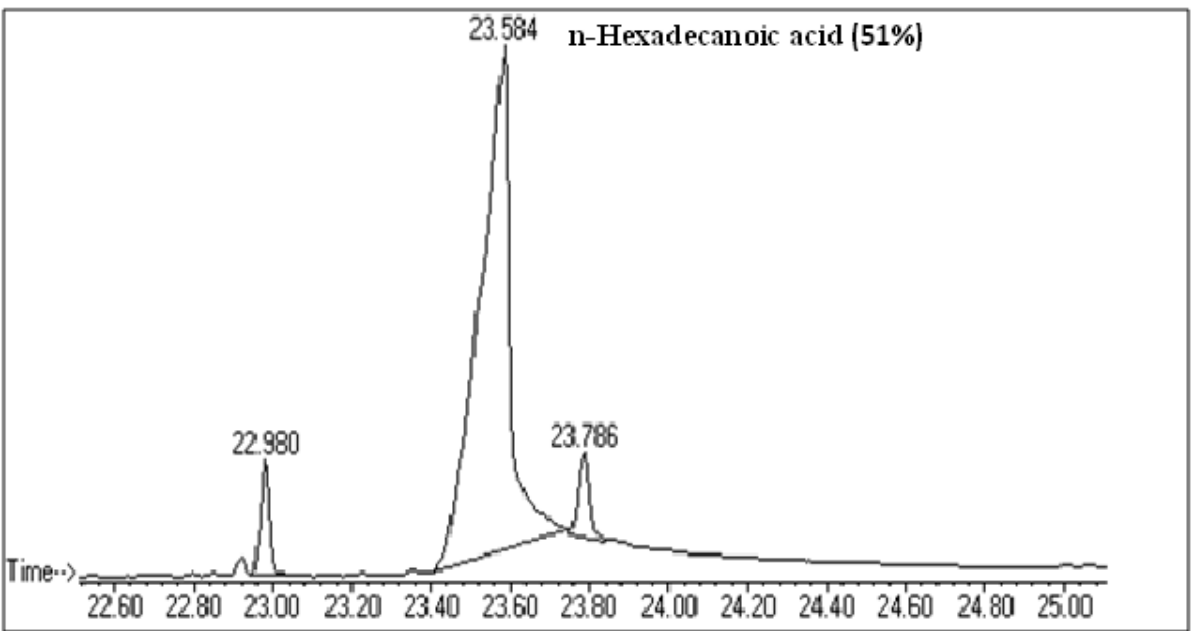

Figure (1): Gas chromatography-mass spectrometry data of purified fraction of methanol/chloroform extracts of Pterocladia capillacea

\section{Conclusion}

Seaweeds collected from Alexandria, Egypt, Mediterranean coast have been shown to possess a specific antibacterial activity. The most interesting species were Pterocladia capillacea and Corallina officinalis as they recorded the highest inhibition zone among the selected algae. These observations showed their importance as a potential source for biological active compounds such as antibacterial substances. The methanol/chloroform extracts possessing high antibacterial effects should be further studied for their therapeutic use. This result could be related to the presence of bioactive metabolites in the selected seaweeds, which are soluble in the organic solvent (methanol/chloroform). Further research studies need to be carried out on other species of seaweeds from the same habitat in order to provide complete data of the antimicrobial potential seaweeds along the Mediterranean coast of Egypt. This study suggests the possibility of using seaweed extracts as natural antimicrobials for the synthesis of novel antibiotics. 


\section{References}

Bianco, A. (1990). The chemistry of Iridoids. In: Rhman AU (Ed) Studies in Natural Products. Elsevier Science B. V Amsterdam, 7: 439-497.

Cabrita, M.; Vale, C. and Rauter, A. (2010). Halogenated compounds from marine algae. Marine Drugs, 8:230-2317.

Eahamban, K and Antonisamy, J.M. (2012). Preliminary phytochemical, UVVIS, HPLC and anti-bacterial studies on Gracilaria corticata. APJTB, 2(2): 568-574.

Feigl, F. (1966). Spot Test in Organic Analysis, $6^{\text {th }}$ Ed. Elsevier Publishing Company, Amsterdam, pp. 584.

Fieser, L. F. and Fieser, M. (1949). Natural Product related to Phenanthrene, Reinhold Publishing Corporation., New York, 3rd Ed., 325.

Fletcher, R.L. (1987). Seaweeds of the British Isles Volume 3 Fucophyceae (Phaeophyceae). British Museum (Natural History), Part 1. Pelagic Publishing Ltd, London, ISBN: 9781907807114, Pages: 370.

Fransworth, N. J. (1966).Biological and phytochemical screening of plants .Journal of Pharmaceutical Sciences, 55: 225.

Govindasamy, C.; Arulpriya, M. and Ruban, P. (2012).Nuclear magnetic resonance analysis for antimicrobial compounds from the red seaweed Gracilaria corticata. Asian Pacific Journal of Tropical Biomedicine(APJTB), 2(1): 329-333.

Hashimoto, K.; Urakami, K.; Fujiwara, Y.; Terada, S. and Watanabe, C. (2001). Determination of residual solvents in pharmaceuticals by thermal desorption-GC/MS, Analytical Sciences, 17( 5): 645-648.

Kalaivani, C. S.;Sathish, S. S.;Janakiraman, N. and Johnson, M. (2012). "GCMS studies on Andrographispaniculata (Burm . f.) Wall. Ex Nees-a medicinally important plant.International Journal of Medicinal and Aromatic Plants, 2: 69-74.

Kolanjinathan, P. Ganesh and P. Saranra j. (2014).Pharmacological importance as seaweeds, a review, World Journal Fish Marine Sciences ,6: 1-15.

McGaw, L.J.;Jäger, A.K.; Van Staden, J. (2002). Isolation of antibacterial fatty acids from Schotia brachypetala. Fitoter, 73, 431-433. 
Mhadhebi, L.;Chaleb, K and Bouraqui, A.(2012). Evaluation of antimicrobial activity of organic fractions of six marine algae from Tunisian Mediterranean Coasts.International Journal of Pharmacy and Pharmaceutical Sciences.,4(1):534-537.

Mohy El-Din, M. Soad and El-Ahwany, M.D.Amani (2016). Bioactivity and phytochemical constituents of marine red seaweeds (Jania rubens, Corallina mediterranea and Pterocladia capillacea). Journal of Taibah University for Science,10:471-484 .

Padmakumar, K. and Ayyakkarmu, K (1997).Seasonal variation of antibacterial and antifingal activities of the extracts of marine algae from Scuthem Coasts of India. Botanica Marina ,40:507 - 515.

Perez, C., M. Paul and P. Bazerque, (1990). Antibiotic assay by agar-well diffusion method. Acta Biol. Med. Exp., 15: 113-115.

Radhika,D.;Veerabahu,C.;Padmakumar,R. and Ayyakkarmu, K.(1997). Seasonal variation of antibacterial and antifingal activities of the extracts of marine algae from Scuthem Coasts of India. BotanicaMarina ,40:507 515.

Rao, P.and Parekh, K. S. (1981). Antibacterial activity of Indian seaweed extracts. Botanica Marina, 24: 577- 582.

Robert-Dernuet, S. (1995). Methodes de dilution. Antibiotiquese antibiogrammes, 131-157.

Robinson, T. (1964). The Organic Constetuents of Higher PlantsBurgress Publishing Company ., New York, 2nd Ed., 190.

Schmidt, J. (1964). Organic Chemistry Oliver and Boyed, Edinburgh and Lanon ,8th Ed., 318.

Seenivasan, R.;Indu, H.;Archana, G. and Geetha, S. (2010).The antibacterial activity of some marine algae from South East coast of India. American Eurasian Journal of agriculture and environmental Science 9 (5): 480489.

Seidel, V. and Taylor, P.W. (2004).In vitro activity of extracts and constituents of Pelagonium against rapidly growing mycobacteria.International Journal of Antimicrobial. Agents, 23: 613-619.

Shellard, E. J. (1957). Practical Plant Chemistry Pitman Medical Publishing Compapany, LYD, London, 53-54. 
Shimizu, Y. (1996). Microalgal metabolites, a new perspective. Annual Review of Microbiology. 50 : 431 - 465.

Taskin ,E.;Ozturk, M.;Taskin, E. and Kurt ,O. (2007). Antibacterial activities of some marine algae from the Aegean Sea (Turkey), African Journal of Biotechnology, 6 (24): 2746-2751.

Tiwari, P.; Kumar, B.; Kaur, M.; Kaur, G. and Kaur, H. (2011). Phytochemical screening and extraction: a Review. Internationale Pharmaceutica Sciencia,1(1): 98-106.

Trease, G.E. and Evans, W.C. (1989). Pharmacognsy. $11^{\text {th }}$ ed., Baillière Tindalland Macmillan Publishers, London; Philadelphia. pp. 784.

Wefky, S. and Ghobrial, M. (2008). Studies on the biodiversity of different solvent extracts of selected marine macro algae against fish pathogens, Research Journal of Microbiology, 3: 673-682.

Yff ,B.; Lindsey, K .L.; Taylor, M.B.;Erasumus, D. G. and Jager, A.K.(2002) . The pharmacological Screening of Pentanisiaprunelloides and the isolation of antibacterial compound Palmitic acid, Journal of Ethnopharmacology, 79 :101-107.

Yin,Y.; Bi, Y. and Chen, S. (2011) . Chemical composition and antifungal activity of cuticular wax from Asian pear fruit .ScientiaHorticulturae, $\mathbf{1 2 9}$ (4) : 577-582 .

Zeheng,Y.i.; Yin-Shan, C. and Hai-Sheng, L. (2001). Screening for antibacterial and antifungal activities from Fujian cost of china with three different solvents. Chinese Journal of Oceanology and limnology, 9(4): 327-331 


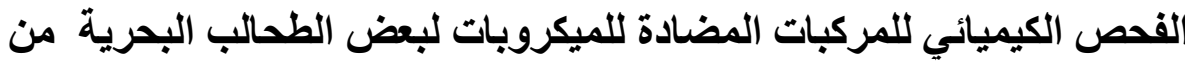

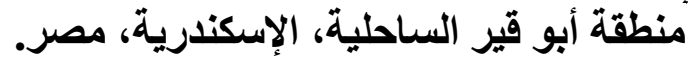

جهاد محمد طه مرسى* ، السيد خلف بخيت ** ، إنتصار عبد المجيذ محمد* ، روحيه عبداللطيف صلاح الدين* .

$$
\begin{aligned}
& \text { *قسم النبات والميكروبيولوجى، كلبة العلوم، جامعة الأزهر(فرع البنات) } \\
& \text { **قسم النبات و الميكروبيولوجى، كلية العلوم، جامعة الأزهر (أسبوط) }
\end{aligned}
$$

لهذة الدراسة تم تجميع أربع أنواع من الطحالب البحرية (بتيروكلاديا كابيلاسيا، كورالينا مديترانيا،

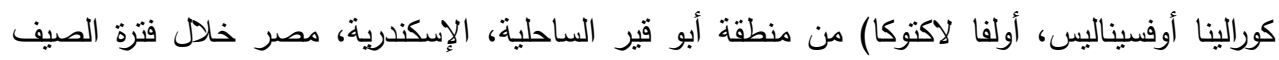

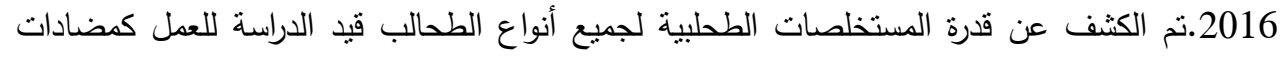
للبكتريا ضد أربعة من البكتريا موجبة الجرام (ستافيلوكوكس اوريوس ، سنافيلوكوكس ابيدرماديس ،

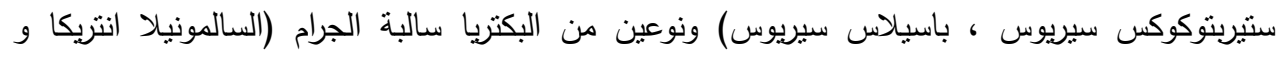
بروتيوس ميرابيليس). أوضحت النتائج أن بكثيريا سيريوس العصويه ونرعين هي الأكثر حساسية بين البكتيريا

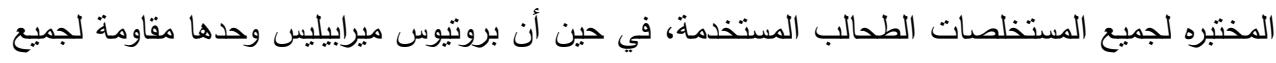

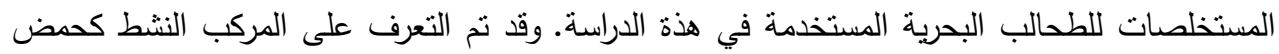

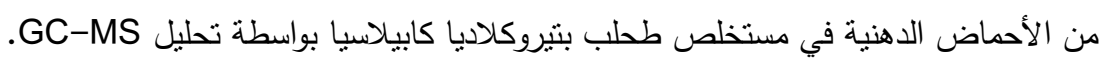

